\title{
A mirigyes bálványfa (Ailanthus altissima (Mill.) Swingle) hazai kutatásainak áttekintése és inváziójának mértéke a hazai élőhelyeken
}

\author{
Demeter András és Czóbel Szilárd \\ Szent István Egyetem, Természetvédelmi és Tájökológiai Tanszék, \\ 2103 Gödöllö, Páter Károly u. 1. \\ e-mail:demetex@gmail.com
}

\begin{abstract}
Összefoglaló: Hazánkban a mirigyes bálványfa a legveszélyesebb fásszárú özönnövény fajok egyike. XIX. századi betelepítése óta sokfelé kivadult, a településekröl az utak mentén is folyamatosan terjed és ma már az ország szinte minden területén előfordul, beleértve a természetközeli élőhelyek többségét. Agresszív térnyerése révén jelentős ökológiai és ökonómiai károkat okoz, ezért az ellene való védekezés elkerülhetetlenné vált. Ehhez a fajjal kapcsolatos releváns hazai ismeretanyag öszszegyüjtése fontos segítséget nyújthat.
\end{abstract}

Kulcsszavak: Ailanthus altissima, elterjedés, inváziós fertőzöttség, Á-NÉR, élőhelyek, felhasználás

\section{Bevezetés}

A Föld biodiverzitásának egyik legfontosabb veszélyeztető tényezője az inváziós fajok terjedése, amelyek természetvédelmi, erdő- vagy mezőgazdasági, humánegészségügyi és ökonómiai problémákat is okozhatnak (Csiszár 2012). A hazánkban 1998-ban, Jósvafön megrendezett „Agresszív adventív növényfajok és a természetvédelem" címü szakmai találkozón összeállították a legveszélyesebb fajok listáját, amely 36 fajt tartalmazott, köztük a mirigyes bálványfát is (http1). A DAISIE (Delivering Alien Invasive Species Inventories for Europe) által összeállított, Európa 100 legveszélyesebb inváziós faját tartalmazó listán szintén szerepel a taxon (http2).

Célunk olyan áttekintést adni a vonatkozó hazai irodalomból, amely a mirigyes bálványfa magyarországi terjedésének különböző vetületeit mutatja be, és informál a faj által leginkább veszélyeztetett élőhelytípusokról is. 


\section{Származása, elterjedése}

Az Ailanthus altissima (Mill.) Swingle őshazája Északkelet-, Közép-Kína és Korea (Gencsi \& Vancsura 1992, Molnár \& Bariska 2002). Innen indult világhódító útjára a XVIII. század közepén, melynek egyes források szerint Párizs (Hu 1979), mások szerint London (Good 1974) volt az első állomása. Az USA-ba is ekkoriban került, ahol elöször díszfaként ültették az északi városokban (Good 1974). Hegi (1924) leírása alapján a XX. század elejére már egész Kelet-Ázsiában, Európában, és Észak-Amerika több államában is meghonosodott. Később minden földrészen elterjedt. Ellenálló képessége és a talajokkal szembeni igénytelensége miatt Európa és Ázsia számos területén sikerrel alkalmazták fásításra. Fájának magas cellulóz tartalma miatt erdészeti ültetvényekbe is telepítették DélAmerikában, Indiában és Új-Zélandon. Szinantróp areája (1. ábra) jelenleg 5 kontinens mérsékeltövi és mediterrán éghajlatú területeit foglalja magába (Kowarik \& Böcker 1984).

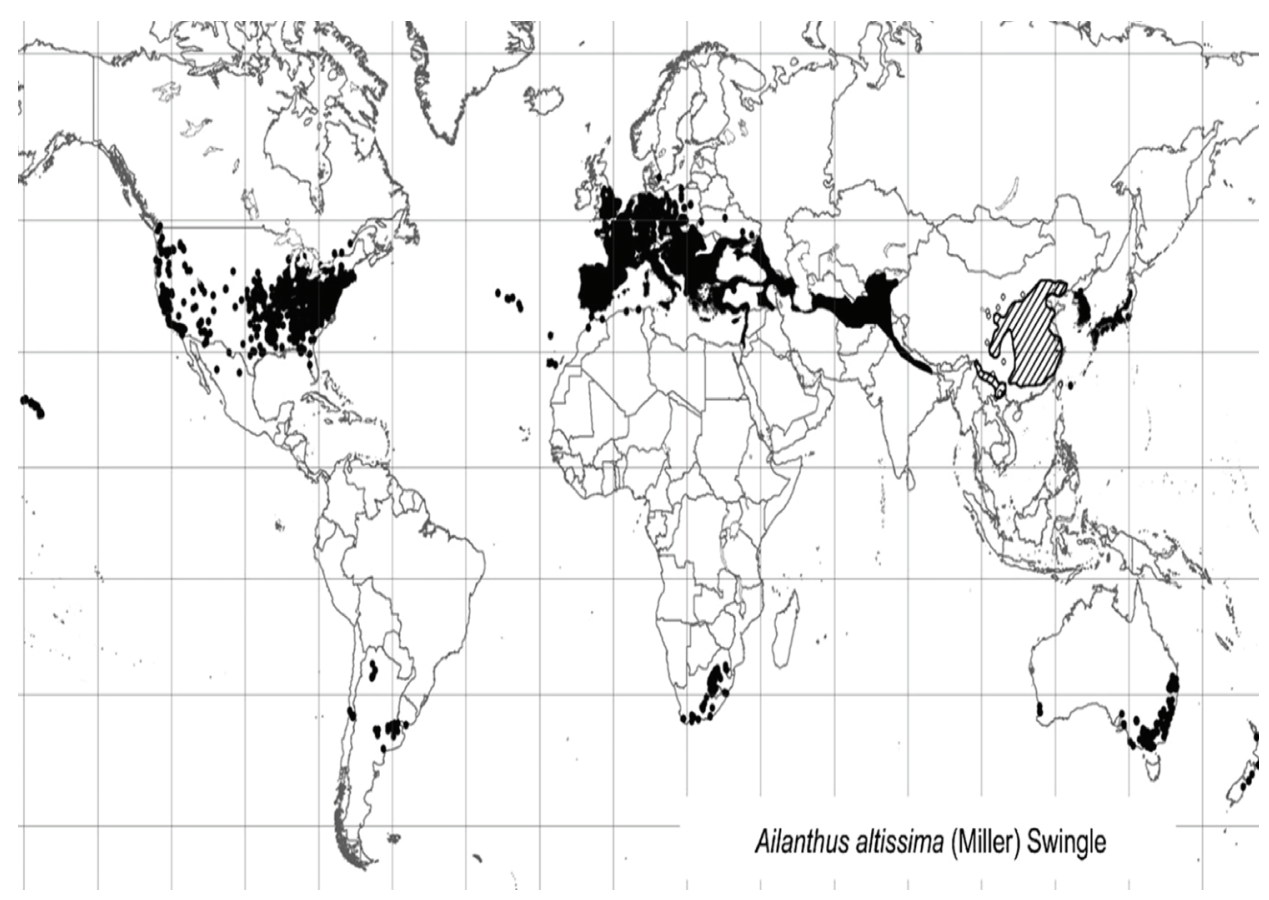

1. ábra. A mirigyes bálványfa elterjedése

(aktuális area feketével, a természetes area csíkozottan jelölt).

(Forrás: E. J. Jager \& E. Welk, AG Chorology, Institute for Biology Halle/Saale) 


\section{Magyarországi elterjedése}

Földrajzi elterjedés

A faj telepítésével kapcsolatos első hazai próbálkozások Bartosságh József (1841, 1843) nevéhez füződnek, aki az 1800-as évek elején ültette villányi birtokára. Később mások is beszámoltak tapasztalataikról, egyre több híradás szólt pozitív tulajdonságairól, sokoldalú használhatóságáról, amely valószínúleg tovább segítette hazai terjedését (Danszky 1964). A XX. század közepére az Alföldön már meghonosodott (Pénzes 1941, Soó \& Jávorka 1951). Soó (1966) és Bartha \& Mátyás (1995) mellett Soó \& Kárpáti (1968) és Simon (1992) is említi gyakori elvadulását, és alföldi állományokba való telepítését. Czúcz (2006) kutatásai alapján a bálványfát a budai Vár kimagaslóan leggyakoribb gyomfa-fajának tartja. Itthon leggyakrabban lakott területekröl, utak mentén terjed. Könnyebben megtelepszik a nyílt, bolygatott talajfelszíneken, ezzel értékes növénytársulásokat is veszélyeztet, például a Kiskunság homokján, a Tornai-karszton, vagy a Szársomlyón (Udvardy 2004).

Napjainkban az ország melegebb klímájú dombvidéki, alföldi területein szinte mindenhol előfordul, viszonylag ritka a Nyugat-Dunántúlon és középhegységeink magasabb régióiban (2. ábra). Előfordulásának súlypontjai közé tartozik a meszes homokú Kiskunság, a Tolnai-hegyhát, a Keszthelyi-hegység és Külső-Somogy (Udvardy \& Zagyvai 2012).

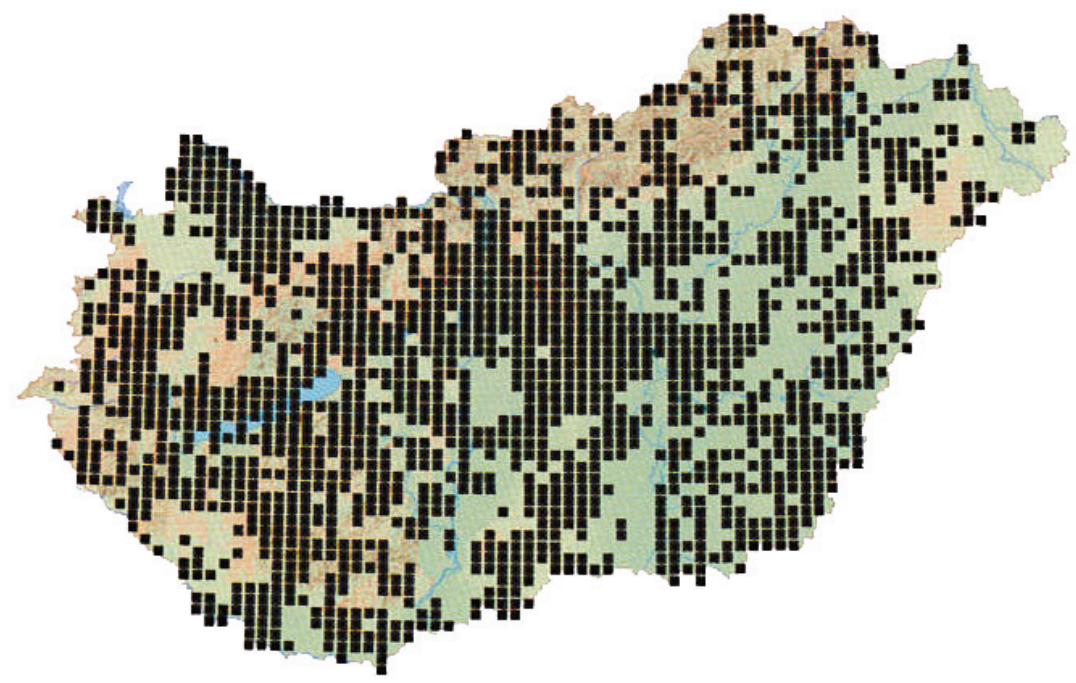

2. ábra. A mirigyes bálványfa hazai elterjedése (Forrás: Udvardy \& Zagyvai 2012). 
Udvardy és Zagyvai (2012) mellett a bálványfa magyarországi elterjedését Csontos \& Tamás (2006), illetve Balogh és mtsai. (2007) is térképezték az elmúlt évtizedben, egymással nem teljesen átfedő térképeket produkálva. Az eltérő area ábrázolásokban - a különböző adatbázisok használata mellett - valószínúleg a faj dinamikus terjedése is szerepet játszik.

A bálványfa terjedését Udvardy (2004) szerint limitálhatja, hogy nehezen viseli a beárnyékolást, valamint a $9^{\circ} \mathrm{C}$-os évi középhőmérsékleti izoterma is határt jelenthet számára. Terjedésének hazánkra vonatkozó biotikus és abiotikus korlátai még kevéssé ismertek, ezért további, ilyen irányú vizsgálatok szükségesek.

Szlovéniai kutatások alapján a magasabban fekvő, savanyú talajú területeket nem kedveli, ezért mészkerülö és montán bükkösökben már kisebb valószínüséggel fordul elö (Carni et al. 2016).

Élőhely alapú elterjedés

Hazánkban a mirigyes bálványfa a MÉTA adatbázisa alapján (http3) 12 különböző Á-NÉR élöhelytípusban van jelen (Demeter et al. 2016), mint a 3 legelterjedtebb özönnövény faj egyike (3. ábra). A bálványfa-fertőzöttséggel érintett élőhelyek többsége Natura 2000-es élöhely is egyben.

A leginkább veszélyeztetett növényközösségek közül 5 gyep- és 6 erdei élőhelytípus. A mirigyes bálványfa egy élőhelytípusban, a „Felnyíló, mészkedvelő lejtő és törmelékgyepek" (H2) a legnagyobb területet elfoglaló, azaz aktuálisan a legveszélyesebb özönnövény fajnak bizonyult. Második legveszélyesebb özön-

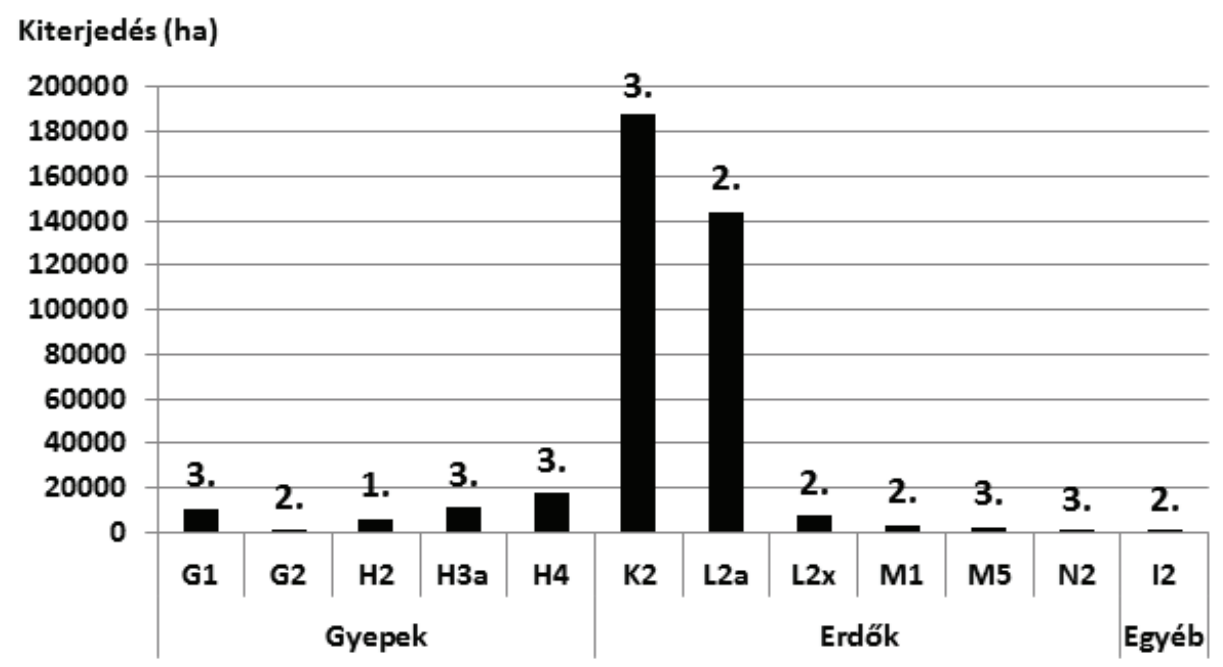

3. ábra. Ailanthus altissima-val fertőzött hazai Á-NÉR élőhelyek kiterjedése. Az oszlopok feletti számok a mirigyes bálványfa özönnövények közötti rangsorát jelzi az adott élőhelyen. 
növényként már jóval több, 5 élőhelytípusban szerepel, mint a „Mészkedvelő nyílt sziklagyepek” (G2), „Cseres-kocsánytalan tölgyesek” (L2a), „Hegylábi és dombvidéki elegyes tölgyesek” (L2x), „Molyhos tölgyes bokorerdők” (M1), és a „Löszfalak és szakadópartok növényzete" (I2). Ezenkívül további 6 élőhelytípusban, a „Nyílt homokpusztagyepeken” (G1), „Lejtőgyepek egyéb kemény alapkőzeten” (H3a), „Félszáraz irtásréteken, száraz magaskórósok és erdőssztyepréteken” (H4), „Gyertyános-kocsánytalan tölgyesekben” (K2), „Homoki borókás-nyárasokban” (M5), „Mészkedvelő erdeifenyvesekben” (N2) inváziójának mértéke a harmadik legtömegesebbnek bizonyult az özönnövények közül. A felsoroltakon kívül a taxon más hazai élőhelytípusokban is jelen van, de azokat nem veszélyezteti ilyen mértékben.

A bálványfa által kolonizált hazai élőhelyek közül két erdei típus (K2 és L2a) országos szinten jelentős elterjedésú, míg a többi jellemzően 10000 hektár alatti. A kisebb kiterjedésủ hazai élőhelyek - mint a „Mészkedvelő nyílt sziklagyepek” (861 ha), „Mészkedvelő erdeifenyvesek” (68 ha) és „Löszfalak és szakadópartok növényzete” (60 ha) - jóval sérülékenyebbek lehetnek a bálványfa folyamatos térhódítása révén.

\section{Morfológiai jellemzöi}

Taxonómiailag a mirigyes bálványfát a Simaroubaceae (bálványfafélék) családjába sorolják (Király et al. 2011). Közepes termetü, 25-30 m-re is megnövő fa. Törzse egyenes, kérge szürke színü, melyen hosszanti irányú sárgásfehér repedések helyezkedhetnek el. Vesszeje vastag, fénylö, sárgás- vagy vörösesbarna, bársonyos felületü, rekeszes béllel rendelkezik. Levelei szórt állásúak, 13-41 levélkéből páratlanul szárnyaltan összetettek. A levélkék tojásdad lándzsásak, kihegyezettek, kellemetlen szagú illóolajokat termelnek. Felemás kétlaki növény, csak porzós virágokkal rendelkező és hímnős virágú példányai is lehetnek. A virágok laza bugákban nyílnak, zöldessárgák, belül gyapjasak, sok nektárt termelnek. Lependék termései csomókban helyezkednek el. A termések 3-4 cm hosszúak, hosszában csavarodottak, lehullás közben vízszintesen forogva oldalirányú haladásra is képesek (Udvardy \& Zagyvai 2012). Udvardy (1997) kutatásai során a bálványfa következő növekedési formáit különítette el, melyeket különböző adottságú élőhelyeken figyelt meg: száraz homoktalajon elegyfaként magas, magányosan állva valamivel alacsonyabb (ún. quercoid) törzset nevel. Szélsőségesen száraz talajon, utak menti sorfaként alacsony törzse és ernyőszerü lombozata (pineoid) fejlődik. Üde környezetben törzse kifejezetten rövid, vagy már tövében (tilio-fagoid) elágazik. Sérülés, visszavágás, vagy visszafagyás miatt pedig idővel áthatolhatatlan sarjtelep (cornoid) alakul ki, mely homoktalajon félgömb alakú állománnyá fejlödik. 


\section{Életmenet jellemzök}

A mirigyes bálványfa fényigényes, az árnyékolást nem kedveli, viszont ennek ellenére is rendkívül sikeres invádor Magyarországon. Terjedését segíti intenzív gyökérsarj-képzése, termésének nagyarányú csírázóképessége és perzisztens magbankja is. A felsoroltakon kívül gyökeréből más növényfajokra ható, növekedést gátló vegyületeket bocsájt a talajba (Udvardy 2004).

Csiszár (2009) a hazai, fásszárú özönnövény fajok allelopátiás potenciálját vizsgálta. Megállapította, hogy mindegyik tartalmaz ilyen hatású vegyületeket, ám ezek közül a bálványfa kiemelkedő hatáserősségünek bizonyult.

Kovács \& Nádasyné Ihárosi (2014) kukorica magokat és csírákat kezelt három különböző koncentrációjú, hajtásból kivont vizes oldattal. Eredményeik igazolták a bálványfa erős allelopátiás hatását, mely jelentősen visszavetette a kukorica csírázását és hajtásnövekedését, legszembetünőbben a gyökér növekedését.

Az eddig taglaltak tehát a faj negatív természetvédelmi megítélését támasztják alá, mivel kiszoríthatja értékes, őshonos növényfajainkat, tönkreteheti természetes és természetközeli növénytársulásainkat. Tulajdonságai, erős sarjadó képessége miatt az egyik legnehezebben irtható özönfajunk. Hazánkban kórokozója, vagy kártevője nem ismert. Az elpusztult egyedek kérgén azonban már megjelenik a hasadt lemezü gomba (Udvardy 2004).

\section{A bálványfa ökológiai hatásai}

Klein Gyula már 1871-ben említést tesz a faj agresszív városi terjedéséről, később Magyar (1960-61) int óvatosságra esetleges telepítésével szemben. Faragó (1964) bálványfáról szóló tanulmányában kitér a faj negatív természetvédelmi vonatkozásaira is: „A bálványfa könnyen behatol más fafajok állományai alá. Ez komoly veszélyt rejt magában, mert gyökérkonkurenciájával és magas vízfelhasználásával nagymértékben csökkenti a más fajú fák növekedését."

Udvardy (1997) négy különböző alapkőzeten (homok, lösz, mészkő, dolomit) vizsgálta a bálványfa állományok növényzetét. A cönológiai csoportok részesedése alapján az indifferens fajok aránya az állományokon kívül és az állományokban egyaránt kiugróan magas volt. A társulásközömbös taxonok aránya homokon és dolomit alapkőzetü állományban nagyobbnak bizonyult. A specialisták aránya csökkent, míg az agresszív kompetitoroké nőtt (Udvardy 1998a, 1998b)

A fővárosban gyakoribb idegenhonos taxonok közül üde, átlagos és beépített környezetben egyaránt a mirigyes bálványfa terjeszkedik a legagresszívebben (Udvardy \& Facsar 1995).

Megállapíthatjuk tehát, hogy azokon a területeken, ahol a mirigyes bálványfa megjelenik és elszaporodik, az eredeti növényzet leromlik, átalakul. Ez először a gyökérből kioldódó allelopátiás vegyületek miatt, később az egyre jelentősebb 
árnyékolás, majd a lehulló, nagy mennyiségü lombtömeg bomlásának nitrogéndúsító hatása miatt következik be. Ezek következtében nitrofil, zavarástürő, árnyékkedvelő növényfajok jelennek meg leginkább ezekben az állományokban. (Udvardy 2004).

A bálványfával fertőzött száraz, lombhullató erdők jövőbeni helyreállítása Trájer és mtsai. (2016) javaslata alapján virágos kőrissel lehetséges a bálványfa folyamatos, egyidejű visszaszorítása mellett utóbbiak hasonló ökológiai türőképessége miatt.

\section{A bálványfa visszaszoritásának tapasztalatai}

A mirigyes bálványfa napjainkban komoly természetvédelmi és gazdasági károkat okoz, ami miatt az ország minden területén negatív megítélés alá esik (Demeter 2014). Az utóbbi évtizedekben több esettanulmány is megjelent a visszaszorítása, irtása során alkalmazott módszerek és tapasztalatok bemutatására. Már Faragó (1964) is ír a faj vegyszeres (Tormona 100 és Tormona 80 arboriciddel történt) irtásának sikerességéről.

Szöllősi és mtsai. (2006) a Fóti Somlyó, védett területen lévő bálványfaállományt manuálisan és vegyszeresen (a környezet szempontjából kíméletes, vágáslap kenéssel) kezelték. Tapasztalatuk szerint vágással, és a feltörő sarjak gyakori eltávolításával a bálványfa gyökértartalékai idővel kimerülnek, de még kevesebb sarj fejlődik, ha a vágáslapokat Garlon oldattal kenik be.

Visszaszorításával kapcsolatban aktuális információkat tartalmaz a 2015-ben megjelent Rosalia kézikönyv, amely több, bálványfairtásra vonatkozó tanulmányt is bemutat az ország különböző területeiről (Boldoghné Szüts 2015, Kocsis 2015, Király et al. 2015, Szabó 2015, Szénási 2015, Szidonya 2015, Tóth 2015, Vadász 2015, Verő \& Csóka 2015). Ezek eredményeit összefoglalva elmondhatjuk, hogy a mirigyes bálványfa rendkívüli sarjadzó képessége révén nagyon nehezen irtható és csak mechanikus módon nem is ajánlott, mert az az állomány gyors terjedéséhez, megerősödéséhez vezethet. Viszont a vegyszeres kezelések sok esetben sikerre vezettek. A fiatalabb egyedeket és sarjakat leggyakrabban permetezik (talajon keresztül ható herbiciddel, Medallon Premiummal vagy glifozát hatóanyagú gyomirtó szerrel) vagy lombkenést (Medallon Premiummal vagy glifozát hatóanyagú gyomirtó szerrel), illetve kéregkenést alkalmaznak. A kéregkenést ma még leginkább kéregsebzéssel (Fozát 480, Figaro, Clinic 480 SL, NASA vagy Medallon Premium vegyszerrel) kombinálva alkalmazzák, de a tapasztalatok szerint hatásos lehet a sebzés nélküli kéregkenés (Medallon Premiummal) is, így az irtás jelentősen egyszerüsödhet. Az idősebb példányoknál az injektálás (Fozát 480, Figaro, Clinic 480 SL, NASA, Taifun 360 vagy Medallon Premium vegyszerrel) a bevált módszer. A glifozát mellett a metszulforon-metil hatóanyagú sze- 
rek alkalmazása is hatékony lehet, mivel erre (a tölggyel ellentétben) a bálványfa magoncok pre-emergensen is érzékenyek. A vegyszeres kezeléseket érdemes őszszel végezni, amikor legintenzívebb a tápanyagforgalom a gyökér felé. Az irtást követően számítani kell a talajban lévő magvak tömeges csírázására (Csiszár \& Korda 2015).

\section{A bálványfa gazdasági jelentösége}

Első hazai telepítése után egyre többen kezdtek el a fajjal foglalkozni és különböző tulajdonságairól hírt adni. Jó növekedése és ellenálló képessége hamar feltünt a szakembereknek. Beauregard (1863) szerint homokon jól nő és már ebben az évben Kalmár (1863) említi, hogy hazánk egyes részein a bálványfát erdőkbe ültetik vagy erdőtalaj előkészítésre használják. Bedő (1867) is alkalmasnak véli leromlott talajok és futóhomok fásítására. Klein tapasztalatai alapján sziklás vidékek fásításán és utcai sorfaként való ültetésén kívül a bálványfa nedvei féregűzőként is jók (Csiszár 2012). Alföldfásításra javasolja, ahogy Rodiczky (1871) is. Közben egyre többen dicsérték faanyagát is. Kalmár (1863) szerint fája olyan kemény és tartós, mint a diófa, ezért asztalosmunkára használható, Bedő (1867) pedig használhatóságát illetően a tölgy és a szilfa fölé helyezi, és hajthatósága miatt kerekesmunkára is alkalmasnak véli. Mágócsy-Dietz amerikai szakirodalomra hivatkozva első számú cölöpfának tartja, és a tölggyel egyező minőségü tüzifának (Csiszár 2012). Gabnay járomfának, kerékagynak, küllőnek vagy akár müasztalosfának ajánlja (Csiszár 2012). Az előbb említettek mellett akadtak olyanok is, akik szerint a bálványfa silány faanyagot ad (Láng 1869). Eleinte Illés is szkeptikusan nyilatkozik róla, fáját puhának és hasznavehetetlennek mondja, tizenöt évvel később viszont a kőrishez hasonlóan jó szerszámfaként dicséri: „,nem hasad, sem nem reped, tehát különösen kerékagynak való" (Csiszár 2012). Roth Erdőmủveléstan (1935) címü könyvéből mégis az derül ki, hogy sok előnyösnek vélt tulajdonsága ellenére sem becsülik, és erdőgazdálkodási jelentősége csekély. Ehhez Magyar (1960-61) hozzáteszi, hogy az Alföldfásítás kapcsán a bálványfa nem váltotta be a hozzá füzött reményeket. Faragó (1964) vizsgálatai igazolták, hogy bár a bálványfa szélsőséges körülmények között is megél, de ott számottevő fatömeget nem ad. A Faipari Kutató Intézet által végzett fizikai és mechanikai vizsgálatok eredményei alapján faanyaga farostgyártásra és papírgyártás alapanyagaként is felhasználható. Faanyagát Molnár (2004) szintén a kőriséhez hasonlítja és alkalmasnak tartja fürészipari rönknek, papír- és rostfának, tüzifának, megfelelő kezelés után beltéri használatra is (Csiszár 2007).

Fehér és Komán (http4) a faj faipari és energetikai célú alkalmazhatóságát vizsgálták. Eredményeik alapján a bálványfa faanyagának müszaki tulajdonságait 
jelentősen befolyásolja a termőhely. Alkalmazását beltérre javasolják, illetve fütőértékét és hamutartalmát tekintve alkalmasnak vélik energetikai felhasználásra is.

Weissmantel (1902) írása alapján a XX. század elején a bálványfát az Ailanthusszövő (Attacus cynthia) tápnövényeként is próbálták hasznosítani a selyem-szövő kiváltására. Ekkorra Franciaország több részén és Dél-Németországban is meghonosodott, de a hazai próbálkozások nem jártak sikerrel.

Az előbb taglaltakon túl a bálványfának méhészeti vonatkozásai is vannak, amelyekről Sztranics (2007a, 2007b) folytatólagosan ír. Jóna (2013) méhészekkel folytatott interjúiból is kiderül, habár a bálványfa méz jó minőségü és különleges aromájú, nagyon ritka, mert a bálványfa bizonytalan mézelő, tömegesen ritkán fordul elö. Lelöhelyei legtöbbször a városokban találhatók, ahova nehéz betelepíteni a méhcsaládokat.

A mirigyes bálványfa szinte minden területen problémát jelent tömeges megjelenésével. Az állami erdőgazdaságok nem tudják értékesíteni, viszont a tisztítási munkálatok során plusz költséget jelent az irtása. A nemzeti park igazgatóságok területén is egyre nagyobb károkat okoz nyitottabb növénytársulásokban való megjelenése és agresszív terjeszkedése miatt, és visszaszorítása hatalmas összegeket emészt fel. A Kiskunsági Nemzeti Park Igazgatóság 5 év alatt több, mint 140 millió Ft-ot költött el ilyen célból. Az általuk küldött költségvetési adatok alapján hektáronkénti költsége megközelítőleg 570 ezer Ft (Demeter et al. 2015).

Kocsis (2015) a Kisalföldön, KEOP pályázati forrásból végzett bálványfa irtási tapasztalatit osztja meg. Beszámolójában a kezelési módtól függően 75000 (mechanikai eltávolítás) és 333520 (kéregkenés) Ft közötti tételeket említ kezelésenként egy hektárra vetítve.

\section{Összefoglalás}

Az eddig taglaltak összegzéseként elmondható, hogy a mirigyes bálványfa jelenleg az egyik legveszélyesebb fásszárú özönnövény fajunk, és az ellene való védekezés természetvédelmi és gazdasági okokból is szükségessé vált. Mivel leggyakrabban lakott területekről, utak mentén terjed, ezért javasolt lenne a viszszaszorítási munkába az önkormányzatok és a lakosság bevonása is, amit a Pilisi Parkerdő Zrt. már kezdeményezett. Fontos, hogy a faj elleni védekezés alapját a vegyszeres permetezés, kenés, vagy injektálás adja, és hogy a magtermő egyedek kiemelt figyelmet kapjanak a további fertőzés elkerülésére. A bálványfa ültetésére vonatkozóan a fásszárú növények védelméről szóló 346/2008. (XII. 30.) Korm. rendelet (http5), továbbá a fásszárú energetikai ültetvények telepítésének engedélyezése, telepítése, müvelése és megszüntetése részletes szabályairól, valamint 
ezen eljárások igazgatási szolgáltatási díjáról megalkotott 45/2007. (VI. 11.) FVM rendelet (http6) egyaránt nem engedélyezi a fafaj telepítését.

Köszönetnyilvánítás - A kutatást a Kutató Kari Kiválósági Támogatás - Research Center of Excellence - 9878-3/2016/FEKUT támogatta. Köszönjük Dr. Grónás Viktornak a fafaj ültetésének jogi szabályozására vonatkozó információkat.

\section{Irodalomjegyzék}

Balogh, L., Dancza, I. \& Király, G. (2007): Preliminary riport on the grid-based mapping of invasive plants in Hungary. - Neobiota 7: 105-114.

Bartha, D. (1999): Magyarország fa és cserjefajai. - Mezőgazda Kiadó, Budapest, 302 pp.

Bartha, D. \& Mátyás, Cs. (1995): Erdei fa- és cserjefajok előfordulása Magyarországon. - Sopron, $223 \mathrm{p}$.

Bartosságh, J. (1841): Beobachtungen und Erfahrungen über den Götterbaum (Ailanthus glandulosa L.) - Ofen, Gyurián u. Bagó. III, 47 p.

Bartosságh, J. (1843): Folytatólagos értesítés a’ bálványfa (Ailanthus glandulosa, Götterbaum) terjedése körül. - Magyar Gazda 3: 298-300.

Beauregard, L. (1863): Fasorok telepítése az alföldi pusztákon. - Erdészeti Lapok 2: 289-298.

Bedő, A. (1867): Becsüljük a bálványfát! - Erdészeti Lapok 6: 530-531.

Boldoghné Szüts, F. (2015): A bálványfa kezelése a tornanádaskai Alsó-hegyen. - In: Csiszár, Á. \& Korda, M. (szerk.): Özönnövények visszaszorításának gyakorlati tapasztalatai. Duna-Ipoly Nemzeti Park Igazgatóság, Budapest, 239 p.

Carni, A., Juvan, N., Dakskobler, I., Kutnar, L., Marinsek, A. \& Silc, U. (2016): Potential distribution of invasive species Ailanthus altissima in forest communities in western part of Slovenia. - In: Agrillo, E., Attore, F., Spada, F., Casella, L., (szerk.): Book of Abstracts. 25th Meeting of European Vegetation Survey. Roma, $115 \mathrm{p}$.

Czúcz, B. (2006): A budai Vár fásszárú adventív flórája. - Kitaibelia 10:73-87.

Csiszár, Á. (2007): Özönnövénnyé vált a sátoros felleng. - Erdészeti Lapok 142: 78-80.

Csiszár, Á. (2009): Allelopathic effects of invasive woody plant species is Hungary. - Acta Silv. Lign. Hung 5: 9-17.

Csiszár, Á. \& Korda, M. (szerk.) (2015): Özönnövények visszaszorításának gyakorlati tapasztalatai. - Duna-Ipoly Nemzeti Park Igazgatóság, Budapest, 239 p.

Csontos, P. \& Tamás, J. (2006): A budai Vár fásszárú adventív flórája. Debrecen. Spread of invasive phanerophytes and further records to the distribution of woody species in Hungary - Tájökológiai Lapok 4: 127-138.

Danszky, I. (szerk.) (1964): Magyarország erdögazdasági tájainak erdöfelújitási, erdötelepitési irányelvei és eljárásai. - OEF Budapest.

Demeter, A. (2014): Kiválasztott özönfajok gazdasági szempontú értékelése. - Természetvédelmi és Tájökológiai Tanszék, Gödöllő, 55 p.

Demeter, A., Kovács, E., Trenyik, P., Csákvári, E. \& Czóbel, Sz. (2016): Economic evaluation of two invasive plant species - preliminary results. 33 p. - In: Agrillo, E., Attorre, F., Spada, F. \& Casella, L. (szerk.) Book of abstracts. 25th International Workshop of the European Vegetation Survey, Rome (Italy), 6-9 April 2016, 115 p. 
Demeter, A., Sarlós, D., Skutai, J., Tirczka, I., Ónodi, G. \& Czóbel, Sz. (2015): Kiválasztott özönfajok gazdasági szempontú értékelése - a fehér akác és a mirigyes bálványfa. - Tájökológiai Lapok 13: 193-201.

Faragó, S. (1964): A bálványfa. - Erdészeti kutatások: az Erdészeti Tudományos Intézet közleményei 60: $87-110$.

Gencsi, L. \& Vancsura, R. (1992): Dendrológia. - Mezőgazda Kiadó, Budapest, 728 p.

Good, R. (1974): The geography of the flowering plants. - Longman, London, 574 p.

Hegi, G. (1924): Illustrierte Flora von Mittel-Europa. - München 5: 80-85.

Hu, S. Y. (1979): Ailanthus. - Arnoldia 39: 29-50.

Jóna, A. K. (2013): A bálványfa (Ailanthus altissima) természetvédelmi, gazdasági és társadalmi hatásai - szakdolgozat. Szent István Egyetem, Gödöllö, 64 p.

Kalmár, T. (1863): A bálványgeszt, vagy sátoros felleng. (Aylanthus glandulosa). - Erdészeti Lapok 2: $358-366$.

Király, G., Virók, V., Molnár, V. A. (2011): Új magyar Füvészkönyv. Magyarország hajtásos növényei. - Aggteleki Nemzeti Park Igazgatóság, Jósvafó, 616 p.

Király, M., Peszlen, R., Szöke, P. (2015): Özönnövények irtási tapasztalatai kísérleti és üzemi körülmények között a Győr környéki homokpusztán. - In: Csiszár, Á. \& Korda, M. (szerk.): Özönnövények visszaszorításának gyakorlati tapasztalatai. Duna-Ipoly Nemzeti Park Igazgatóság, Budapest, $239 \mathrm{p}$.

Kelin, Gy. (1871): Az alianthus-fák. -Természettudományi közlöny 3:150.

Kocsis, G. I. (2015): Bálványfa irtás a kisalföldi homokvidéken. - In: Csiszár, Á. \& Korda, M. (szerk.): Özönnövények visszaszorításának gyakorlati tapasztalatai. Duna-Ipoly Nemzeti Park Igazgatóság, Budapest, 239 p.

Kovács, A. Z. \& Nádasyné, I. E. (2014): A bálványfa (Ailanthus altissima (Mill.) Swingle), a selyemkóró (Asclepias syriaca L.) és a kaukázusi medvetalp (Heracleum mantegazzianum Somm. et Lev.) allelopatikus hatása kukoricára. - Növényvédelem 50: 537-546.

Kowarik, I. \& Böcker, R. (1984): Zur Verbreitung, Vergesellschaftung und Einbürgerung des Götterbaumes (Ailanthus altissima (Mill.) SWINGLE) in Mitteleuropa. - Tuexenia 4: 9-29.

Láng, G. (1869): A futó homok megkötése és beerdősítése. - Erdészeti Lapok 8: 488-503.

Magyar, P. (1960-61): Alföldfásitás I-II. - Akadémiai Kiadó, Budapest, 1197 p.

Molnár, S. \& Bariska, M. (2002): Magyarország ipari fái. - Szaktudás Kiadó Ház, Budapest, 210 p.

Pénzes, A. (1941): Budapest élövilága. - Királyi Magyar Természettudományi Társulat, Budapest, $236 \mathrm{p}$.

Rodiczky, J. (1871): Az ailanthus-fák ügyéhez. - Természettudományi Közlöny 3: 201.

Roth, Gy. (1935): Erdömüveléstan I-II. - Röttig-Romwalter, Sopron, 971 p.

Simon, T. (1992): A magyarországi edényes flóra határozója. Harasztok-virágos növények. Tankönyvkiadó, Budapest, 892 p.

Soó, R. (1966): A magyar flóra és vegetáció rendszertani-növényföldrajzi kézikönyve. I-VI. - Akadémiai Kiadó, Budapest.

Soó, R. \& Jávorka S. (1951): A magyar növényvilág kézikönyve I-II. - Akadémiai Kiadó, Budapest, $537 \mathrm{p}$.

Soó, R. \& Kárpáti, Z. (1968): Növényhatározó. II. köt. Magyar flóra. Harasztok-virágos növények. - Tankönyvkiadó, Budapest, 846 p.

Szabó, R. (2015): Magyarországi adatok a bálványfa magoncainak herbicidérzékenységéről. - In: Csiszár, Á. \& Korda, M. (szerk.): Özönnövények visszaszoritásának gyakorlati tapasztalatai. Duna-Ipoly Nemzeti Park Igazgatóság, Budapest, 239 p. 
Szénási, V. (2015): Özönnövények visszaszorítása a Turai Legelő Természetvédelmi Területen. In: Csiszár, Á. \& Korda, M. (szerk.): Özönnövények visszaszorításának gyakorlati tapasztalatai. Duna-Ipoly Nemzeti Park Igazgatóság, Budapest, 239 p.

Szidonya, I. (2015): A bálványfa irtásának tapasztalatai a Mecseki Parkerdő területén. - In: Csiszár, Á. \& Korda, M. (szerk.): Özönnövények visszaszorításának gyakorlati tapasztalatai. Duna-Ipoly Nemzeti Park Igazgatóság, Budapest, 239 p.

Szöllösi, T. I., Tóth, M. \& Kalapos, T. (2006): Removal experiment of Ailanthus altissima on the 'Fóti Somlyó' hill, Hungary and subsequent changes in the vegetation. 80-81 p. - In: Book of abstracts, 1st European Congress of Conservation Biology, Eger (Hungary), 22-26 August 2006, $187 \mathrm{p}$.

Sztranics, Zs. (2007a): A bálványfa. - Méhészet 55: 16-17.

Sztranics, Zs. (2007b): A bálványfa II. - Méhészet 55: 18.

Tóth, M. (2015): Bálványfa a Fóti-Somlyó Természetvédelmi Területen - egy sikeres kezelési tevékenység rövid története. - In: Csiszár, Á. \& Korda, M. (szerk.): Özönnövények visszaszorításának gyakorlati tapasztalatai. Duna-Ipoly Nemzeti Park Igazgatóság, Budapest, 239 p.

Trájer, A., Hammer, T., Bede-Fazakas, Á., Schoffhauzer, J. \& Padisák, J. (2016): The comparison of the potential effect of climate change on the segment growth of Fraxinus ornus, Pinus nigra and Ailanthus altissima on shallow, calcareous soils. - Appl. Ecol. Environ. Res. 14: 161-182. http:// dx.doi.org/10.15666/acer/1403 161182

Udvardy, L. (1997): Fásszárú adventiv növények Budapesten és környékén. - Kandidátusi értekezés. Kertészeti és Élelmiszeripari Egyetem Növénytani Tanszék és Soroksári Botanikus Kert, Budapest, $126 \mathrm{p}$.

Udvardy, L. (1998a): Budapest környéki bálványfa (Ailanthus altissima) állományok florisztikaicönológiai vizsgálata. - Kitaibelia 3: 343-346.

Udvardy, L. (1998b): Spreading and coenological circumstances of tree of heaven, [Ailanthus altissima (MILL.) SWINGLE] in Hungary. - Acta Botanica Hung. 41: 299-314.

Udvardy, L. (2004): Bálványfa. - In: Mihály, B. \& Botta-Dukát, Z. (szerk.): Özönnövények. TermészetBÚVÁR Alapítvány Kiadó, Budapest, 408 p.

Udvardy, L. \& Facsar, G. (1995): Weed vegetation of Budapest as an indicator of changes in environments's quality. - $9^{\text {th }}$ EWRS (European Weed Research Society) Symposium Budapest 1995: „Challenges for Weed Science in a Changing Europe. Perspektiven für die Unkrautforschung im veranderten Europa." 10-12 July 1995 Proceedings vol. 1: 107-112.

Udvardy, L. \& Zagyvai, G. (2012): Mirigyes bálványfa (Ailanthus altissima [Mill.] Swingle). - In: Csiszár, Á. (szerk.): Inváziós növényfajok Magyarországon. Nyugat-magyarországi Egyetem Kiadó, Sopron, 364 p.

Vadász, Cs. (2015): Az inváziós növényfajok visszaszorításának tapasztalatai a Felső-kiskunsági Turjánvidéken. - In: Csiszár, Á. \& Korda, M. (szerk.): Özönnövények visszaszorításának gyakorlati tapasztalatai. Duna-Ipoly Nemzeti Park Igazgatóság, Budapest, 239 p.

Verö, Gy. \& Csóka, A. (2015): Özönnövény-kezelési tapasztalatok a nagykőrösi pusztai tölgyesekben és a Turjánvidéken. - In: Csiszár, Á. \& Korda, M. (szerk.): Özönnövények visszaszorításának gyakorlati tapasztalatai. Duna-Ipoly Nemzeti Park Igazgatóság, Budapest, 239 p.

Weissmantel, V. (1902): Az Ailanthus-szövő (Attacus cynthia). - Rovartani lapok 9: 21.

\section{Elektronikus hivatkozások:}

http1: http://www.termeszetvedelem.hu/index.php?pg=sub 643

http2: $\mathrm{http}: / /$ www.europe-aliens.org/speciesFactsheet.do? speciesId $=16970$

http3: http://www.novenyzetiterkep.hu/ 
http4: Fehér, S. \& Komán, Sz. (2014): A bálványfa (Ailanthus altissima) faipari és energetikai célú alkalmazhatósága: http://erdo-mezo.hu/2014/12/30/a-balvanyfa-ailanthus-altissima-faipari-esenergetikai-celu-alkalmazhatosaga/

http5: http://net.jogtar.hu/jr/gen/hjegy doc.cgi?docid=A0800346.KOR

http6: http://net.jogtar.hu/jr/gen/hjegy_doc.cgi?docid=A0700045.FVM

\title{
Review of Hungarian studies and extent of invasion of tree of heaven (Ailanthus altissima (Mill.) Swingle) in Hungarian habitats
}

\author{
András Demeter and Szilárd Czóbel \\ Department of Conservation and Landscape ecology, Szent István University, \\ H-2103 Gödöllö, Páter K. street 1., Hungary, \\ e-mail:demetex@gmail.com
}

Tree of heaven is one of the most dangerous woody stemmed plant species in Hungary. Since its XIXth century introduction it has run wild in many places, from the settlements it is continously spreading along the roads and now occurs in almost all areas of the country including most of the close to natural habitats. By its aggressive spreading it causes significant ecological and economic damages, so defense against it became inevitable. To this collection of relevant hungarian knowledge can help a lot.

Keywords: Ailanthus altissima, spreading, invasive infection, A-NER, habitats, utilization 